\title{
The Translation Strategies of Metaphors in Dee's Supernova: the Knight, the Princess, and the Falling Star
}

\author{
Alexander I. Kaparang \& Adventina Putranti \\ alexanderkaparang@gmail.com \& putranti@usd.ac.id \\ Department of English Letters, Universitas Sanata Dharma
}

\begin{abstract}
The metaphors in Dee's Supernova: The Knight, The Princess, and The Falling Star are translated in various ways. This paper discusses the translation of the metaphors in the work. Newmark's Translation Strategies and Metaphor Translation Procedures are employed as the theoretical framework. The result shows that the majority of the translation of the metaphors manages to maintain their metaphorical expressions. Imitative Translation is mostly employed while the rest applies Functional Communication. Establishing the link between Translation Strategies and Metaphor Translation Procedures underlying the principle of translating metaphors is highlighted. It is also found out that the sense of each metaphor becomes the key in translating metaphors.
\end{abstract}

Keywords: metaphors, translation strategies, translation procedures

\section{Introduction}

One of the most prominent characteristics of Dee's writing in one of her novels, Supernova: Ksatria, Putri, dan Bintang Jatuh (Supernova: the Knight, the Princess, and the Falling Star) is the use of a fairly large numbers of figures of speech. The most dominant figure of speech employed is metaphor alongside personification and simile. The three of them are under the same heading of tropes having the nature of comparison (Keraf, 1981:136). This study focuses on metaphors and how they are translated as they show not only a considerable number of applications, but also more distinctive features compared to personification and simile. The process of translation they undergo is intriguing since the concepts which do not normally belong together (in one particular language) now need to find their way to another language. This study reveals what happens to the object, image, and sense of each metaphor in the novel.
The discussion may start by considering that a writer must have a purpose in employing metaphor. For the majority of readers, it is easy to notice and understand that the purpose is to produce certain effects on the readers. The effects, as explained by Keraf, could be for clarity, emphasis, beauty, humor, or anything else (1981:129). Those effects are expected to achieve some objectives, developing characterization or advancing storylines for instances. For that reason, to translate metaphors is a challenge. It is a challenge since the translation has to be a bridge enabling readers to not only understand the story they read, but also to experience the effects created. The process of translation in which whether the translation manages to preserve meaning while keeping the elevated and enhanced language from the source text becomes a crucial question to ask. Examining the result and the process of translation used is ensuring the words mean what they are meant and the metaphors are well utilized, thus well delivered. 


\section{Translation Strategies}

There are 30 sentences in this 231-page novel explicitly containing 31 metaphorical expressions based on Keraf's definition of metaphor. They could be divided into two based on the methods employed: Imitative Translation and Functional Communication. The two are according to Newmark's theory on translation strategies consisting translation methods and translation procedures. Translation methods deal with the whole text, such as sentences, while procedures with smaller chunks of the text, such as words.
Imitative Translation refers to Word-forWord Translation, Literal Translation, Faithful Translation and Semantic Translation. In other words, the focus is on both content and form.

Meanwhile, Functional Communication includes Adaptation, Free Translation, Idiomatic Translation and Communicative Translation. It emphasizes the content/message. The definition of each method is as follows:

\begin{tabular}{|c|c|c|}
\hline NO & METHODS & EXPLANATION \\
\hline \multicolumn{3}{|c|}{ IMITATIVE TRANSLATION } \\
\hline 1 & Word-for-Word Translation & $\begin{array}{l}\text { Preserving the word order and translating the words by their most } \\
\text { common meanings }\end{array}$ \\
\hline 2 & Literal Translation & $\begin{array}{l}\text { Converting the grammatical constructions to the closest target } \\
\text { language structure, but still translating them by their most common } \\
\text { meanings }\end{array}$ \\
\hline 3 & Faithful Translation & $\begin{array}{l}\text { Keeping precise contextual meaning of the source text within the } \\
\text { constraints of the target language grammatical structure }\end{array}$ \\
\hline 4 & Semantic Translation & $\begin{array}{l}\text { Similar to faithful translation, but taking more account of the } \\
\text { aesthetic value of the source text }\end{array}$ \\
\hline \multicolumn{3}{|c|}{ FUNCTIONAL COMMUNICATION } \\
\hline 1 & Adaptation & $\begin{array}{l}\text { Adapating the source text culture to the target text culture and then } \\
\text { rewriting the text }\end{array}$ \\
\hline 2 & Free Translation & $\begin{array}{l}\text { Producing the translation without the style, form, or content of the } \\
\text { source text }\end{array}$ \\
\hline 3 & Idiomatic Translation & $\begin{array}{l}\text { Reproducing the message of the source text, but having a tendency } \\
\text { to distort nuances of meaning by prefering colloquallism and idioms } \\
\text { which do not exist in the source text }\end{array}$ \\
\hline 4 & Communicative Translation & $\begin{array}{l}\text { Presenting the exact contextual meaning of the source text in a way } \\
\text { both content and language are acceptable to the readers }\end{array}$ \\
\hline
\end{tabular}

Quoted from Newmark (1988:81)

Word-for-Word Translation, Adaptation and Idiomatic Translation were not found among the data. The data show that there are 27 expressions applying Imitative Translation (7 Literal Translation, 17 Faithful Translation, 3 Semantic Translation) and 3 applying Functional Communication (1 Free Translation, 2 Communicative Translation).
The followings are the examples for each category. 


\section{1.a. Imitative Translation - Literal Translation}

\begin{tabular}{|c|}
\hline SOURCE TEXT \\
\hline $\begin{array}{c}\text { [Cinta tidak membebaskan. Konsep itu memang utopis.] } \\
\text { Cinta itu tirani. }\end{array}$ \\
\hline TARGET TEXT \\
\hline Love is a tyrant. \\
\hline
\end{tabular}

The target language (TL) sentence is considered literal translation since each word is translated by its denotative meaning, not contextual meaning, and the grammatical construction is adjusted to the closest target language structure. The phrase cinta itu is translated as "love" and the word tirani is translated as "a tyrant". Based on Kamus Indonesia Inggris, it is undeniable that tirani could also be translated as "tyranny", not "tyrant", but either way they are still regarded as denotative meaning. It is because "a tyrant" basically has the same definition of tyranny: unfair use of power and control. Thus, the idea of tyranny is already there. For that reason, both are regarded as denotative meaning.

Meanwhile, in terms of grammatical construction, there is an addition of the word "is" and the article "a". They are not regarded as expansion, but they are seen as an adjustment to the target language grammar. The word "is" is needed to act as a verb, which is basically a requirement in forming a sentence. The article "a" is needed to refer to a general type of thing, which has been the rule in the target language. This adjustment is the reason why this sentence is considered applying literal translation and not word-forword translation.

\section{1.b. Imitative Translation - Faithful Translation}

\begin{tabular}{|c|}
\hline SOURCE TEXT \\
\hline $\begin{array}{c}\text { Kami adalah jalinan satelit yang saling membelit. } \\
\text { [Mengelilingi satu planet yang menarik kami laksana } \\
\text { magnet. }]\end{array}$ \\
TARGET TEXT \\
\hline$\frac{\text { We are satellites on parallel orbits, circling around the }}{\text { same planet. }}$ \\
\hline
\end{tabular}

The sentence is considered faithful translation since it is translated by not only its denotative meaning, but also its contextual meaning. Additionally, the translation is still within the constraint on the target language grammar. The phrase Kami adalah jalinan satelit, which is the beginning of the sentence, is translated by its denotative meaning, "We are satellites".

The word jalinan (alignment) signifies the idea of plural form. It is because it carries the idea of "to be aligned", which is only possible in a group of things, instead of only one single thing. This idea is then translated by forming the plural form of "satellite", which is "satellites". The next phrase, yang saling membelit (intertwining), acting as a modifier, is translated contextually as "(being) on parallel orbits". That is why the first two phrases are translated as "We are satellites on parallel orbits" rather than "We are intertwined satellites" which could be perceived as a translation by its denotative meaning.

However, the resulted translation seems to undergo a transposition (change of grammar) in which it is one sentence coming from two different sentences. This marks another indication of translation based on context. The idea of the later sentence in the source text, Mengelilingi satu planet yang menarik kami laksana magnet (orbitting a planet pulling us like a magnet) is put as a modifier in the translated text. What becomes the indication of contextual translation is the fact that the sentence is not translated literally. It only translates the main idea, "circling around the same planet", and ignores the supporting idea, yang menarik kami laksana magnet (pulling us like a magnet). This is why this sentence is considered as applying faithful translation.

\section{1.c. Imitative Translation - Semantic Translation}

\begin{tabular}{|c|}
\hline SOURCE TEXT \\
\hline [Tidak ada yang tahu betapa sulitnya pertanyaan itu. \\
Re dipaksa untuk menyusuri kelamnya gua masa kecil \\
yang penuh lumpur. Mungkin inilah gorong-gorong \\
saluran sekresi psikologis. Tidak heran Freud tergila- \\
\hline
\end{tabular}




\begin{tabular}{|c|}
\hline $\begin{array}{l}\text { gila.] Tak ada yang lebih menarik daripada } \\
\text { menyaksikan seseorang menyelam ke septic tank } \\
\text { kotorannya sendiri. }\end{array}$ \\
\hline TARGET TEXT \\
\hline $\begin{array}{l}\text { She does not realize how difficult that question is. It } \\
\text { forced him back into the small dark cave of his } \\
\text { childhood, which was filled with mud and slime. The } \\
\text { muck that clogged his subconscious. No wonder Frued is } \\
\text { so popular. Nothing is more interesting than watching a } \\
\text { man drowning in the swamp of his own being. }\end{array}$ \\
\hline
\end{tabular}

The sentence is considered a semantic translation since the translation supports the source text in terms of meaning (within the constraint on target language grammar) and also takes the choice of words into account. That means there has been more consideration in choosing certain words, which are not only based on their denotative and connotative meanings, but also based on how they work and function in the target language.

Explicitly this sentence could be regarded as a translation applying faithful translation. However, the functional equivalents of the word menyelam (to dive) and the phrase "septic tank" indicate that there is more than just a contextual translation. First, the word menyelam carries a denotative meaning of "to dive". Based on Longman Dictionary of Contemporary English (2011), it basically means "to swim under water". Meanwhile, the word "drowning" basically also means "to go under water". However, it differs in a way that there is no sense of control in drowning. This different sense is realized in the translation as a form of interpretation. The sense of this particular word might be different, but the sense of the idea of the text is still the same.

Menyelam ke septic tank (diving into a septic tank) is clearly a very unpleasant activity. Thus, it might not feel like diving, it might feel more like drowning anyway. To use drowning rather than diving is to use a more appropriate diction since "drowning" conveys a more negative sense than diving. This strengthens the impression that this sentence wants to convey, which is how uncomfortable this activity is.
Second, the phrase "septic tank" carries a denotative meaning of "an underground container for holding human waste". Meanwhile, the word "swamp" means "a land which is always very wet or covered with a layer of water". Those two might seem different, but they are contextually the same. It is because it is stated that "the swamp is full of his own being". It means that the idea is still the same: the place described is filthy. However, the translated version does not exactly specify the place as "septic tank". Nonetheless, they contain the same thing. To use "swamp of his own being" rather than "septic tank" is to consider how the word corresponds with the idea of drowning. Swamp, in general, must be bigger and deeper than a septic tank and it is more common to portray someone drowning in a swamp than in a septic tank. This whole explanation is based on how the words are defined and how they function based on Kamus Besar Bahasa Indonesia Edisi Keempat and Longman Dictionary of Contemporary English.

\section{2.a. Functional Communication - Free Translation}

\begin{tabular}{|c|}
\hline SOURCE TEXT \\
\hline [Tidak ada yang tahu betapa sulitnya pertanyaan itu. \\
Re dipaksa untuk menyusuri kelamnya gua masa kecil \\
yang penuh lumpur.] Mungkin inilah gorong-gorong \\
saluran sekresi psikologis. [Tidak heran Freud tergila- \\
gila. Tak ada yang lebih menarik daripada \\
menyaksikan seseorang menyelam ke septic tank \\
kotorannya sendiri.] \\
TARGET TEXT \\
\hline $\begin{array}{c}\text { She does not realize how difficult that question is. It } \\
\text { forced him back into the small dark cave of his } \\
\text { childhood, which was filled with mud and slime. The } \\
\text { muck that clogged his subconscious. No wonder Frued } \\
\text { is so popular. Nothing is more interesting than } \\
\text { watching a man drowning in the swamp of his own } \\
\text { being. }\end{array}$ \\
\hline
\end{tabular}

The sentence is considered free translation since it explicitly does not imitate the source text in terms of style, form and content, yet still manages to communicate the message. In the source text, there is a description of a place where all the so-called 
"psychological waste" is put. The word sekresi signifies the idea that those "psychological waste" are supposed to get rid of. It is because, according to Kamus Besar Bahasa Indonesia Edisi Keempat (2008), sekresi (secretion) is where all the waste belongs. Since the context here is on someone's state of mind, it is reasonable to say that the waste refers to the waste in one's mind: his psychological state. In other words, or in a more realistic description, it talks about things in the past that someone wants to forget. This idea is then interpreted and translated as "the muck that clogged his subconscious". "The muck" refers to the "psychological waste" which is the idea behind the word sekresi. Meanwhile, "clogged" here refers indirectly to goronggorong (tunnel/water channel), which is not uncommon to be blocked or clogged. This is in reference to Kamus Inggris Indonesia Edisi Yang Diperbarui. "Subconscious" refers to the word psikologis (psychological) as well as to the whole particular context in which this description is talking about something occurring in someone's mind. This whole explanation justifies why the message of the source text is still delivered although it has different style, form, and content.

\section{2.b. Functional Communication - Communicative Translation}

\begin{tabular}{|c|}
\hline SOURCE TEXT \\
\hline $\begin{array}{c}\text { [Tanpa kamu, ide-ide di otakku seperti mulut tanpa } \\
\text { lidah. Tidak ada artinya.] Kamu adalah pesawat yang } \\
\text { menyeberangkan nuansa dalam kepalaku ke format }\end{array}$ \\
\hline yang bisa dimengerti. \\
\hline TARGET TEXT \\
\hline$\frac{\text { You are the means by which the nuances in my mind }}{\text { find expression in a way other people can }}$ \\
understand.
\end{tabular}

The sentence is considered a communicative translation since it explicitly does not imitate the source text. As it still preserves the content, it must be not a free translation. The translation focuses on a more reasonable content and language of the target text. It means it applies communicative translation strategy. It could be seen that the source text is translated in a clearer and shorter way. The contents which are recognized as necessary are kept: "you", "nuances", "mind", and "understand". They are then expressed briefly by dismissing the parts which might be considered to be avoidable: mulut tanpa lidah (mouth without a tongue), pesawat (airplane), menyeberangkan (carrying), and format. Those words potentially do not articulate the meaning well if they are translated imitatively. Even if they could articulate the meaning well, the translation is not a must. They are there as elevated words which function as complements. The main idea is still carried by the other content words mentioned before. That is why it is justifiable to classify this as communicative translation.

\section{The Metaphors}

In 30 sentences, there are 31 metaphorical expressions found, 27 of them are maintained while the other 4 are not. The data are categorized as maintained metaphor when they satisfied the requirements of a metaphor in terms of form and/or meaning, which are based on Newmark's theory on metaphor. There are 27 data maintaining the metaphorical expressions. Those data can be categorized into three: Original Metaphor into Original Metaphor, Stock Metaphor into Stock Metaphor, and Original Metaphor into Dead Metaphor. Besides, each metaphor in this part is also analyzed by reviewing the Metaphor Translation Procedures (MTP) employed.

\begin{tabular}{|l|}
\hline \multicolumn{1}{|c|}{ Metaphor Translation Procedures } \\
\hline Reproducing the same image \\
Replacing the ST image with another compatible TT \\
image \\
Turning the metaphor into a simile \\
Turning the metaphor into a simile along with the \\
sense \\
Turning the ST image into its sense \\
Deleting the metaphor \\
Describing the metaphor
\end{tabular}

Quoted from Newmark (1988:81)

Here is an example of the maintained metaphor. 


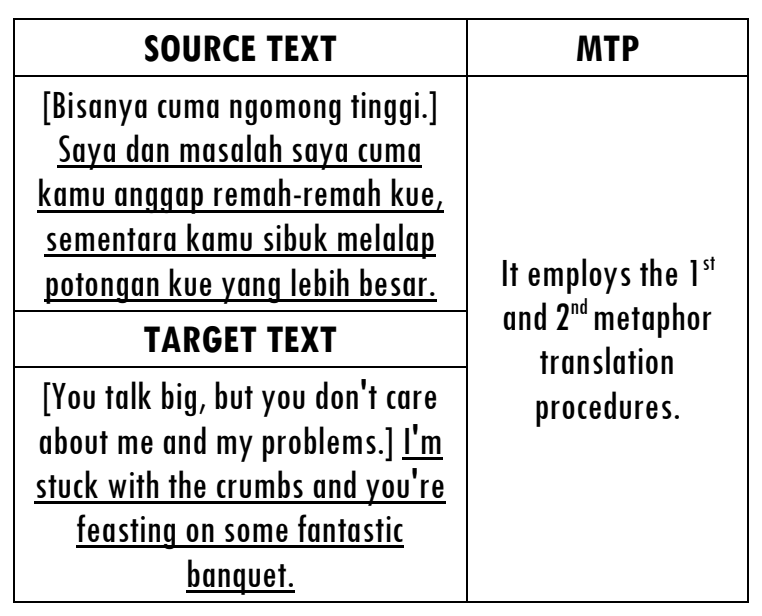

First, it is an original metaphor since the comparison is based on what happens in the story. It is about a person believing that the person she talks to sees her as insignificant. Second, the original metaphor is translated as an original metaphor by reproducing the same object and image, as well as replacing an image with another equal image in the target text. It could be seen that the objects, saya (me) and masalah saya (my problems) are still translated as the same objects although they experience transposition. The two images however are treated differently. The first image, remah-remah kue is turned into the same image, "crumbs". The second image, potongan kue yang lebih besar (bigger piece of cake) is turned into a different yet functionally equal image, "fantastic banquet". It means that the original metaphor is maintained by using the first and second metaphor translation procedures, that is reproducing the same image and replacing the ST image with another compatible TT image.

Meanwhile, the data are categorized as non-maintained metaphor when they do not satisfy the requirements of a metaphor in terms of form and/or meaning, based on Newmark's theory on metaphor. Four data are not classified as metaphor anymore. Here is an example.

\begin{tabular}{|c|c|}
\hline SOURCE TEXT & MTP \\
\hline $\begin{array}{c}\text { Mungkin itu adalah kali pertama } \\
\text { Anda mencicipi kewarasan. }\end{array}$ & $\begin{array}{c}\text { It employs the } 5^{\text {th }} \\
\text { metaphor } \\
\text { translation } \\
\text { TARGET TEXT }\end{array}$ \\
\cline { 1 - 1 } $\begin{array}{c}\text { It may be the first sane thing you've } \\
\text { ever done. }\end{array}$ & \\
\hline
\end{tabular}

The TL sentence is no longer classified as a metaphor since the translation does not show anymore comparison. In the source text, the metaphor is indicated by the phrase mencicipi kewarasan (to taste sanity). "Sanity" here is considered something which could be tasted like food, while it is actually an abstract noun. "To taste" is a verb which works on food while food is not an abstract thing. It is a concrete object. This feature is not realized in the translation. The idea is expressed in a different way which is more explicit and contains no more figure of speech. On the other hand, the translation shows that there is still a point of similarity between the source text and the target text. This indicates that the sense between the two of them is still the same. The image is turned into its sense, as a process of metaphor translation, but it does not result in form of metaphor. In conclusion, the metaphor is not maintained since the translation undergoes a paraphrase process.

\section{Conclusion}

By looking at the Metaphor Translation Procedures, the relevance to the Translation Strategies is established. Out of 27 metaphorical expressions which use Imitative Translation, there are 20 of them applying reproducing the same image. One of them applies reproducing the same image and replacing the ST image with another compatible TT image at the same time. This is to explain why there are 28 expressions found in the text. Four expressions are using a replacement the ST image with another compatible TT image, 3 expressions turn the metaphor into a simile, and 1 expression turns the ST image into its sense. Meanwhile, out of 3 Functional Communication, the three of them turn the ST image into its sense. 
This result shows that it is a priority to reproduce the same object and image in the target text, but, in times when it is not done, the translation maintains the sense. This is especially highlighted in the 3 Functional Communicative Translation in which all of them turn the ST image into its sense. In conclusion, the key to translating metaphor, both by using general Translation Strategies and specific Metaphor Translation Procedures, is the sense of the metaphor.

\section{References}

Brikci, Nouria and Judith Green. A Guide to Using Qualitative Research Methodology. London: Medecins Sans Frontieres, 2007.

Chesterman, Andrew and Jenny Williams. The Map: A Beginner's Guide to Doing Research in Translation. Manchester: St. Jerome Publishing, 2002.

Echols, John M and Hassan Shadily. Kamus Indonesia Inggris Edisi Ketiga. Jakarta: PT. Gramedia Pustaka Utama, 1998.

Echols, John M and Hassan Shadily. Kamus Inggris Indonesia Edisi Yang Diperbarui. Jakarta: PT. Gramedia Pustaka Utama, 2014.

Hanafi, Nurachman. Teori dan Seni Menerjemahkan. Ende: Percetakan Arnoldus, 1986.

Kamus Besar Bahasa Indonesia Edisi Keempat. Jakarta: PT. Gramedia Pustaka Utama, 2008.

Kardimin. Pintar Menerjemah: Wawasan Teoritik dan Praktek. Yogyakarta: Pustaka Pelajar, 2013.

Keraf, Gorys. Diksi dan Gaya Bahasa. Jakarta: PT. Gramedia, 1984.
Lefevere, André. Translating Literature: Practice and Theory in a Comparative Literature Context. New York City: The Modern Language Association of America, 1992.

Lengari, Yoana Gita. "The Accuracy, The Acceptability, and Translation Strategies of Indonesian Metaphors Translation in Twilight". Undergraduate Thesis. Yogyakarta: English Letters, Universitas Sanata Dharma, 2012.

Loescher, W. Translation Performance, Translation Process and Translation Strategies. Tuebingen: Guten Narr, 1991.

Longman Dictionary of Contemporary English. Harlow: Pearson Education Limited, 2011.

Nida, Eugene and Charles Taber. The Theory and Practice of Translation. Leiden: E.J.Brill, 1974.

Newmark, Peter. A Textbook of Translation. Hertfordshire: Prentice Hall, 1988.

Newmark, Peter. Approaches to Translation. Oxford: Pergamon Press, 1981.

Rasari, Titis. "A Study of The Translation of The Metaphors in George Bernard Shaw's Man and Superman into Indonesian in Akhmad Santoso's Manusia Adimanusia". Undergraduate Thesis. Yogyakarta: English Letters, Universitas Sanata Dharma, 2011.

Suryawinata, Zuchridin and Sugeng Hariyanto. Translation: Bahasan Teori \& Penuntun Praktis Menerjemahkan. Yogyakarta: Kanisius, 2003. 